(c) American Dairy Science Association, 2004.

\title{
Genotype $\times$ Environment Interaction for Yield and Somatic Cell Score with Automatic and Conventional Milking Systems
}

\author{
H. A. Mulder, ${ }^{1}$ A. F. Groen, ${ }^{1}$ G. De Jong, ${ }^{2}$ and P. Bijma ${ }^{1}$ \\ ${ }^{1}$ Animal Breeding and Genetics Group, Wageningen University, \\ PO Box 338, 6700 AH Wageningen, The Netherlands \\ ${ }^{2}$ NRS, PO Box 454, 6800 AL Arnhem, The Netherlands
}

\section{ABSTRACT}

The objective of this study was to quantify genotype by environment interaction $(\mathrm{G} \times \mathrm{E})$ between automatic milking systems (AMS) and conventional milking systems (CMS) for test-day milk, fat, and protein yield and for test-day somatic cell score (SCS) in The Netherlands. The $\mathrm{G} \times \mathrm{E}$ was studied in 2 ways: 1 ) between AMS farms and CMS farms in the same period and 2) within farms comparing the period before introduction of AMS with the period after introduction of AMS. For both sub-objectives, a separate data set was generated. Test-day records were used to be more flexible with respect to the introduction date of AMS. Multivariate, fixed regression, test-day sire models were used to estimate variance components.

Genetic correlations between AMS farms and CMS farms in the same period were $0.93,>0.99,0.98$, and 0.79 for test-day milk yield, fat yield, protein yield, and SCS, respectively. Genetic correlations within farms between the period before and after introduction of AMS were lower for production traits and higher for SCS: $0.89,0.91,0.87$, and $>0.99$, respectively, for testday milk yield, fat yield, protein yield, and SCS. Heterogeneity of variance was observed between AMS and CMS in both data sets. Especially the residual variance increased with automatic milking. As a consequence, the heritability tended to be lower for automatic milking. It was concluded that effects of $\mathrm{G} \times \mathrm{E}$ are small between AMS and CMS. Therefore, AMS farms can select sires accurately based on national rankings.

(Key words: genotype by environment interaction, automatic milking, milk production, somatic cell score)

Abbreviation key: AMS = automatic milking system, $\mathbf{C M S}=$ conventional milking system, $\mathbf{G} \times \mathbf{E}=$ genotype by environment interaction, HTD $=$ herd-test date.

Received September 23, 2003.

Accepted December 21, 2003.

Corresponding author: H. A. Mulder; E-mail: herman.mulder@ wur.nl.

\section{INTRODUCTION}

Genotype by environment interaction $(\mathbf{G} \times \mathbf{E})$ is the phenomenon that different environments do not affect performances of different genotypes equally (Falconer, 1989). In dairy cattle, $\mathrm{G} \times \mathrm{E}$ is usually of minor importance within countries or between countries with similar management systems (Weigel et al., 2001). However, if management systems are more different, genetic correlations tend to be lower (Swalve et al., 2001; Weigel et al., 2001; König et al., 2002).

In The Netherlands, the number of farms with automatic milking systems (AMS) is increasing. In 2002, about 520 farms were milking with AMS with an average milking frequency between 2.6 and 2.8 (Hogeveen et al., 2001; Kruip et al., 2002). The majority of the Dutch farms are still milking with conventional milking systems (CMS), which usually means milking 2 times/ $\mathrm{d}$ in a milking parlor. Because of increased milking frequency, AMS are expected to increase milk production (Erdman and Varner, 1995), which was not always significantly observed (Rasmussen et al., 2001; Kruip et al., 2002). Somatic cell count tended to be lower with higher milking frequency, but, in most studies, an increase in SCC was observed when AMS was introduced (Van der Vorst and Hogeveen, 2000; Rasmussen et al., 2001; Kruip et al., 2002).

In general, AMS have an influence on milk yield and SCC at least on a phenotypic level. These influences are driven by differences in environment and differences in management and milking frequency. Therefore, the environment of dairy cows could be different in such a way that $\mathrm{G} \times \mathrm{E}$ might occur between AMS and CMS.

The objective of this study was to quantify $\mathrm{G} \times \mathrm{E}$ between AMS and CMS for milk, fat, and protein yield and SCS. The objective was studied in 2 ways: 1 ) between AMS farms and CMS farms (control farms) in the same period and 2) within farms comparing the period before introduction of AMS with the period after introduction of AMS.

\section{MATERIAL AND METHODS}

\section{Data and Edits}

First-lactation test-day records were obtained from the Dutch herdbook and milk recording organization, 
Table 1. Descriptive figures of the "between farms" data set with test-day records from 2000 and 2001 from automatic milking system (AMS) farms and conventional milking system (CMS) farms for production traits, SCC, and SCS.

\begin{tabular}{|c|c|c|c|c|c|c|}
\hline & \multicolumn{3}{|c|}{ Production traits } & \multicolumn{3}{|c|}{ SCS } \\
\hline & AMS & CMS & Total $^{3}$ & AMS & CMS & Total $^{1}$ \\
\hline Test-day records, no. & 69,776 & 71,043 & 140,819 & 63,953 & 66,248 & 130,201 \\
\hline Cows, no. & 14,109 & 12,635 & 26,744 & 13,638 & 12,629 & 26,267 \\
\hline Sires, no. & 883 & 804 & 951 & 883 & 804 & 905 \\
\hline $\mathrm{HTD}^{1}{ }^{1}$ no. & 3745 & 4215 & 7960 & 3406 & 3724 & 7130 \\
\hline Herds, no. & 256 & 229 & 485 & 252 & 223 & 475 \\
\hline \multicolumn{7}{|l|}{ Milk yield, kg } \\
\hline Mean & 24.44 & 24.31 & 24.38 & 24.47 & 24.30 & 24.39 \\
\hline SD & 6.29 & 5.63 & 5.96 & 6.27 & 5.62 & 5.95 \\
\hline \multicolumn{7}{|l|}{ Fat yield, g } \\
\hline Mean & 1053 & 1065 & 1059 & 1054 & 1065 & 1059 \\
\hline $\mathrm{SD}$ & 249 & 227 & 239 & 249 & 224 & 237 \\
\hline \multicolumn{7}{|l|}{ Protein yield, g } \\
\hline Mean & 840 & 841 & 840 & 841 & 842 & 842 \\
\hline $\mathrm{SD}$ & 192 & 170 & 181 & 191 & 169 & 180 \\
\hline \multicolumn{7}{|l|}{$\mathrm{SCC}^{2} \times 10^{3} / \mathrm{mL}$} \\
\hline Mean & - & - & - & 162 & 136 & 149 \\
\hline SD & - & - & - & 445 & 385 & 416 \\
\hline \multicolumn{7}{|l|}{$\mathrm{SCS},{ }^{2} \log _{2}(\mathrm{SCC})$} \\
\hline Mean & - & - & - & 6.06 & 5.88 & 5.97 \\
\hline SD & - & - & - & 1.62 & 1.58 & 1.60 \\
\hline
\end{tabular}

NRS. Data originated from 2 groups of farms: (1) AMS farms milking at least one year with AMS and (2) CMS farms (control group). About 2 CMS farms were selected per AMS farm in such a way that average milk production, breed composition, hair color, and herd size were similar to the AMS farm. Test-day records were used because a test-day model can estimate breeding values more accurately by accounting for time-specific environmental effects (Schaeffer et al., 2000; Swalve, 2000). Therefore, it is easier to handle the situation that AMS farms are changing at a certain time from conventional milking to automatic milking. The initial data set contained 2,707,031 first-lactation test-day records from 302 AMS farms and 584 CMS farms. Records were collected between March 18, 1988 and March 29, 2002. The AMS farms had records of automatic milking as well as records of conventional milking before introduction of AMS. For each test day, milk, fat, and protein yields were measured. Somatic cell count was available for most test days (69\%). Milk recording procedures for AMS and CMS were as described in Peeters and Galesloot (2002). At least a part of the data of the AMS farms used in this study was also used in the studies of Van der Vorst and Hogeveen (2000) and Kruip et al. (2002).

Edit rules as described in the NRS handbook (NRS, 2002) were followed as much as possible and supple- mented by some additional edits specific for this study. Cows were excluded if the breed composition consisted of $<75 \%$ Holstein-Friesian. Records of CMS farms that had records coded with automatic milking were excluded as were records of AMS farms that changed back to conventional milking. To ensure connectedness of the data, 5 daughters per sire and 5 cows per herd-test date (HTD) were required. For production traits (milk, fat, and protein yield) and SCC, 2 separate data sets were formed because some test-day records had no SCC measurement.

To study $\mathrm{G} \times \mathrm{E}$ between AMS farms and CMS farms, data subsets for production traits and SCC were generated based on records during 2000 and 2001 ("between farms" data set). Records of AMS farms were extracted from all AMS farms in the edited data sets (258 farms for production and 252 farms for SCC). The CMS farms were randomly sampled in such a way that the number of records of CMS farms is similar to the number of records of AMS farms (229 farms for production and 223 farms for SCC). Some descriptive figures of the "between farms" data subsets are shown in Table 1.

The $\mathrm{G} \times \mathrm{E}$ between AMS and CMS was also studied within farms comparing different periods ("within farms" data set). Records of all AMS farms (258 farms for production and 252 farms for SCC) were extracted from 3 different periods with respect to the introduction 
Table 2. Descriptive figures of the "within farms" data set for production traits, SCC, and SCS with testday records of farms (258 farms for production traits; 252 farms for SCS) from 3 periods: 1) within 1 yr before introduction of automatic milking system (AMS) (Period 1), 2) within $1 \mathrm{yr}$ after introduction of AMS (Period 2), and between 1 and 2 yr after introduction of AMS (Period 3).

\begin{tabular}{|c|c|c|c|c|c|c|}
\hline & \multicolumn{3}{|c|}{ Production traits } & \multicolumn{3}{|c|}{ SCS } \\
\hline & Period 1 & Period 2 & Period 3 & Period 1 & Period 2 & Period 3 \\
\hline Test-day records, no. & 36,967 & 42,088 & 31,662 & 30,837 & 37,522 & 28,719 \\
\hline Cows, no. & 7757 & 9346 & 8070 & 7264 & 8900 & 7651 \\
\hline Sires, no. & 436 & 562 & 485 & 405 & 519 & 449 \\
\hline $\mathrm{HTD},{ }^{1}$ no. & 2219 & 2356 & 1872 & 1851 & 2101 & 1712 \\
\hline \multicolumn{7}{|l|}{ Milk yield, kg } \\
\hline Mean & 24.27 & 24.42 & 24.58 & 24.18 & 24.42 & 24.60 \\
\hline SD & 5.83 & 6.29 & 6.29 & 5.86 & 6.26 & 6.27 \\
\hline \multicolumn{7}{|l|}{ Fat yield, $\mathrm{g}$} \\
\hline Mean & 1047 & 1046 & 1065 & 1041 & 1046 & 1066 \\
\hline SD & 235 & 251 & 251 & 236 & 250 & 250 \\
\hline \multicolumn{7}{|l|}{ Protein yield, $\mathrm{g}$} \\
\hline Mean & 842 & 840 & 848 & 839 & 840 & 849 \\
\hline SD & 180 & 194 & 191 & 181 & 193 & 191 \\
\hline \multicolumn{7}{|l|}{$\mathrm{SCC},{ }^{2} \times 10^{3} / \mathrm{mL}$} \\
\hline Mean & - & - & - & 140 & 162 & 163 \\
\hline SD & - & - & - & 382 & 432 & 443 \\
\hline \multicolumn{7}{|l|}{$\mathrm{SCS},{ }^{2} \log _{2}(\mathrm{SCC})$} \\
\hline Mean & - & - & - & 5.91 & 6.07 & 6.07 \\
\hline SD & - & - & - & 1.59 & 1.62 & 1.62 \\
\hline
\end{tabular}

date of AMS: 1) all test days within 1 yr before introduction of AMS, 2) all test days within $1 \mathrm{yr}$ after introduction of AMS, and 3) all test days between 1 and $2 \mathrm{yr}$ after introduction of AMS. These periods could be different for herds because of differences in date of introduction of AMS. Some descriptive figures of the "within farms" data subsets are shown in Table 2.

A full pedigree file was available for all cows in the initial data set. For each data subset, a reduced pedigree file was generated including sire of the cow and the parents and grandparents of the sire (sire model). Unknown animals in the pedigree defined one phantom genetic group.

\section{Models}

A fixed regression test-day sire model was used to limit computational demand. To account for lactation stage, the Wilmink curve was used (Wilmink, 1987). Because SCC is not normally distributed, a log transformation was carried out. Somatic cell score was calculated as $\log _{2}$ (SCC), which is a slightly different transformation than proposed by Ali and Shook (1980). Testday milk yield, fat yield, protein yield, and SCS were analyzed with the same model. In scalar notation the model is:

$$
\begin{gathered}
\mathrm{y}_{\mathrm{ijklmnop}}=\mathrm{HTD}_{\mathrm{i}}+\text { age }_{\mathrm{j}}+\text { year }_{\mathrm{k}} * \text { season }_{1}+ \\
\Sigma \mathrm{b}_{\mathrm{m}: \mathrm{l}} \mathrm{x}_{\mathrm{m}}+\mathrm{s}_{\mathrm{n}}+\mathrm{p}_{\mathrm{o}}+\mathrm{e}_{\mathrm{ijk} \text { lmnop }}
\end{gathered}
$$

where

$\mathrm{y}_{\mathrm{ijklmnop}}=$ test-day record $\mathrm{p}$ of cow o of sire $\mathrm{n}$ with age at calving $\mathrm{j}$, year of calving $\mathrm{k}$, season of calving $\mathrm{l}$, lactation stage $\mathrm{m}$, and HTD i;

$\mathrm{HTD}_{\mathrm{i}}=$ fixed effect of herd-test-day subclass $\mathrm{i}$;

age $_{j}=$ fixed effect of age at first calving class j;

year $_{\mathrm{k}}=$ fixed effect of year of calving $\mathrm{k}$;

season $_{\mathrm{i}}=$ fixed effect of season of calving $\mathrm{l}$;

$b_{\mathrm{m}: \mathrm{l}}=$ fixed regression coefficients of the Wilmink lactation curve on days in milk $\mathrm{m}$ nested within season of calving 1 ;

$\mathrm{x}_{\mathrm{m}}=$ days in milk $\mathrm{m}$;

$\mathrm{s}_{\mathrm{n}}=$ random additive sire effect of sire $\mathrm{n}$ of cow 0 ;

$\mathrm{p}_{0}=$ random permanent animal effect of cow 0 ; and

$\mathrm{e}_{\mathrm{ijklmnop}}=$ random residual effect of test-day record $\mathrm{p}$.

The permanent animal effect consisted of permanent environmental effects, like in animal models, and genetic effects excluding the sire effect, which is estimated separately. Note that the permanent animal effect is within lactation.

Multivariate models were used to analyze the data subsets. Two environments were considered in the "between farms" data set: 1) automatic milking on AMS farms and 2) conventional milking on CMS farms. 
Three environments were considered in the "within farms" data set corresponding to the 3 periods with respect to the introduction date of AMS. Therefore, the "between farms" data set was analyzed with a bivariate model, and the "within farms" data set was analyzed with a trivariate model. Fixed effects were estimated regardless of milking system or period. In matrix notation, these models are formulated as

"Between farms" data set (1):

$$
\left[\begin{array}{l}
\mathbf{y}_{\mathbf{a}} \\
\mathbf{y}_{\mathbf{c}}
\end{array}\right]=\mathbf{X b}+\left[\begin{array}{cc}
\mathbf{Z}_{\mathbf{a}} & \mathbf{0} \\
\mathbf{0} & \mathbf{Z}_{\mathbf{e}}
\end{array}\right]\left[\begin{array}{l}
\mathbf{s}_{\mathbf{a}} \\
\mathbf{s}_{\mathbf{c}}
\end{array}\right]+\left[\begin{array}{cc}
\mathbf{W}_{\mathbf{a}} & \mathbf{0} \\
\mathbf{0} & \mathbf{W}_{\mathbf{c}}
\end{array}\right]\left[\begin{array}{l}
\mathbf{p}_{\mathbf{a}} \\
\mathbf{p}_{\mathbf{c}}
\end{array}\right]+\left[\begin{array}{l}
\mathbf{e}_{\mathbf{a}} \\
\mathbf{e}_{\mathbf{c}}
\end{array}\right]
$$

"Within farms" data set (2):

$\left[\begin{array}{l}\mathbf{y}_{1} \\ \mathbf{y}_{2} \\ \mathbf{y}_{3}\end{array}\right]=\mathbf{X b}+\left[\begin{array}{ccc}\mathbf{Z}_{1} & \mathbf{0} & \mathbf{0} \\ \mathbf{0} & \mathbf{Z}_{2} & \mathbf{0} \\ \mathbf{0} & \mathbf{0} & \mathbf{Z}_{3}\end{array}\right]\left[\begin{array}{l}\mathbf{s}_{1} \\ \mathbf{s}_{2} \\ \mathbf{s}_{3}\end{array}\right]+\left[\begin{array}{ccc}\mathbf{W}_{1} & \mathbf{0} & \mathbf{0} \\ \mathbf{0} & \mathbf{W}_{2} & \mathbf{0} \\ \mathbf{0} & \mathbf{0} & \mathbf{W}_{3}\end{array}\right]\left[\begin{array}{l}\mathbf{p}_{1} \\ \mathbf{p}_{2} \\ \mathbf{p}_{3}\end{array}\right]+\left[\begin{array}{l}\mathbf{e}_{1} \\ \mathbf{e}_{2} \\ \mathbf{e}_{3}\end{array}\right]$

where

$\mathbf{y}_{\mathbf{i}}=$ vector with test-day yield or test-day SCS of environment $i$,

$\mathbf{b}=$ [age at first calving; year-season of calving; lactation curve coefficients; HTD] = vector with all fixed effects,

$\mathbf{s}_{\mathbf{i}}=$ vector with random additive sire effects for environment i,

$\mathbf{p}_{\mathbf{i}}=$ vector with random permanent animal effects for environment $i$,

$\mathbf{e}_{\mathbf{i}}=$ vector with random residual effects for environment $i$, and

$\mathbf{X}, \mathbf{Z}_{\mathbf{i}}, \mathbf{W}_{\mathbf{i}}=$ incidence matrices.

Sire effects, permanent animal effects, and residual effects were assumed to follow a multivariate normal distribution with mean and variance:

$$
\left[\begin{array}{l}
\mathbf{s} \\
\mathbf{p} \\
\mathbf{e}
\end{array}\right] \sim \mathrm{N}\left(\left[\begin{array}{l}
\mathbf{0} \\
\mathbf{0} \\
\mathbf{0}
\end{array}\right],\left[\begin{array}{lll}
\mathbf{G} & \mathbf{0} & \mathbf{0} \\
\mathbf{0} & \mathbf{P} & \mathbf{0} \\
\mathbf{0} & \mathbf{0} & \mathbf{R}
\end{array}\right]\right)
$$

and

$$
\begin{gathered}
\operatorname{Var}[\mathbf{s}]=\mathbf{G}=\mathbf{C} \otimes \mathbf{A} \text { with } \mathbf{C}_{\mathbf{1}}=\left[\begin{array}{cc}
\sigma_{\mathrm{s}, \mathrm{a}}^{2} & \sigma_{\mathrm{s}, \mathrm{ac}} \\
\sigma_{\mathrm{s}, \mathrm{ac}} & \sigma_{\mathrm{s}, \mathrm{c}}^{2}
\end{array}\right] \\
\text { or } \mathbf{C}_{\mathbf{2}}=\left[\begin{array}{ccc}
\sigma_{\mathrm{s}, 1}^{2} & \sigma_{\mathrm{s}, 12} & \sigma_{\mathrm{s}, 13} \\
\sigma_{\mathrm{s}, 12} & \sigma_{\mathrm{s}, 2}^{2} & \sigma_{\mathrm{s}, 23} \\
\sigma_{\mathrm{s}, 13} & \sigma_{\mathrm{s}, 23} & \sigma_{\mathrm{s}, 3}^{2}
\end{array}\right]
\end{gathered}
$$

$$
\begin{gathered}
\operatorname{Var}[\mathbf{p}]=\mathbf{P}=\mathbf{I}_{\mathbf{o}} \otimes \mathbf{P} \text { with } \mathbf{P}_{\mathbf{1}}=\left[\begin{array}{cc}
\sigma_{\mathrm{pe}, \mathrm{a}}^{2} & \sigma_{\mathrm{pe}, \mathrm{ac}} \\
\sigma_{\mathrm{pe}, \mathrm{ac}} & \sigma_{\mathrm{pe}, \mathrm{c}}^{2}
\end{array}\right] \\
\text { or } \mathbf{P}_{\mathbf{2}}=\left[\begin{array}{ccc}
\sigma_{\mathrm{pe}, 1}^{2} & \sigma_{\mathrm{pe}, 12} & \sigma_{\mathrm{pe}, 13} \\
\sigma_{\mathrm{pe}, 12} & \sigma_{\mathrm{pe}, 2}^{2} & \sigma_{\mathrm{pe}, 23} \\
\sigma_{\mathrm{pe}, 13} & \sigma_{\mathrm{pe}, 23} & \sigma_{\mathrm{pe}, 3}^{2}
\end{array}\right] \\
\operatorname{Var}[\mathbf{e}]=\mathbf{R}=\mathbf{I}_{\mathbf{p}} \otimes \mathbf{E} \text { with } \mathbf{E}_{\mathbf{1}}=\left[\begin{array}{cc}
\sigma_{\mathrm{e}, \mathrm{a}}^{2} & 0 \\
0 & \sigma_{\mathrm{e}, \mathrm{c}}^{2}
\end{array}\right] \\
\text { or } \mathbf{E}_{\mathbf{2}}=\left[\begin{array}{ccc}
\sigma_{\mathrm{e}, 1}^{2} & 0 & 0 \\
0 & \sigma_{\mathrm{e}, 2}^{2} & 0 \\
0 & 0 & \sigma_{\mathrm{e}, 3}^{2}
\end{array}\right]
\end{gathered}
$$

where

$\mathbf{A}=$ relationship matrix of the sires,

$\sigma_{\mathrm{s}, \mathrm{i}}^{2}=$ sire variance of environment $\mathrm{i}$,

$\sigma_{\mathrm{s}, \mathrm{ij}}=$ sire covariance between environment $\mathrm{i}$ and $\mathrm{j}$,

$\mathbf{I}_{\mathbf{o}}=$ identity matrix of $\mathrm{o} * \mathrm{o}$ where $\mathrm{o}$ is number of cows,

$\sigma_{\mathrm{pe}, \mathrm{i}}^{2}=$ permanent animal variance of environment $i$,

$\sigma_{\mathrm{pe}, \mathrm{ij}}=$ permanent animal covariance between environment $\mathrm{i}$ and $\mathrm{j}$,

$\mathbf{I}_{\mathbf{p}}=$ identity matrix of $\mathrm{p} * \mathrm{p}$ where $\mathrm{p}$ is number of records,

$\sigma_{\mathrm{e}, \mathrm{i}}^{2}=$ residual error variance of environment $\mathrm{i}$,

$\mathbf{C}_{1}, \mathbf{P}_{1}, \mathbf{E}_{1}=$ variance-covariance matrices for "between farms" data set, and

$\mathbf{C}_{2}, \mathbf{P}_{2}, \mathbf{E}_{2}=$ variance-covariance matrices for "within farms" data set.

Permanent animal effects of AMS farms and CMS farms were uncorrelated in the "between farms" data set because cows could not have records in both milking systems $\left(\sigma_{\mathrm{pe}, \mathrm{ac}}=0 ; \mathbf{P}_{\mathbf{1}}\right.$ was estimated as a diagonal matrix). Permanent animal effects between Periods 1 and 3 were uncorrelated $\left(\sigma_{\mathrm{pe}, 13} \approx 0\right.$ and was not estimable) in the "within farms" data set because cows could not have records in both periods. Cows could have records in Periods 1 and 2 or 2 and 3, so that other covariances between permanent animal effects could be estimated. Residual error terms were uncorrelated between AMS farms and CMS farms in the "between farms" data set and between periods in the "within farms" data set. Variance components were estimated with the program ASREML (Gilmour et al., 1999). 


\section{Genetic Parameters}

Heritability for each trait in environment i (AMS or CMS or Periods 1,2 , or 3 ) was calculated as:

$$
\mathrm{h}_{\mathrm{i}}^{2}=\left(4 * \sigma_{\mathrm{s}, \mathrm{i}}^{2}\right) /\left(\sigma_{\mathrm{s}, \mathrm{i}}^{2}+\sigma_{\mathrm{pe}, \mathrm{i}}^{2}+\sigma_{\mathrm{e}, \mathrm{i}}^{2}\right)
$$

where $\sigma_{\mathrm{s}, \mathrm{i}}^{2}=$ sire variance, $\sigma_{\mathrm{pe}, \mathrm{i}}^{2}=$ permanent animal variance, and $\sigma_{\mathrm{e}, \mathrm{i}}^{2}=$ residual variance in environment i. Repeatability for each trait in environment $i$ was calculated as:

$$
\mathrm{r}_{\mathrm{i}}=\left(\sigma_{\mathrm{s}, \mathrm{i}}^{2}+\sigma_{\mathrm{pe}, \mathrm{i}}^{2}\right) /\left(\sigma_{\mathrm{s}, \mathrm{i}}^{2}+\sigma_{\mathrm{pe}, \mathrm{i}}^{2}+\sigma_{\mathrm{e}, \mathrm{i}}^{2}\right) .
$$

Notice that repeatability estimates of sire models have the same expectation as repeatability estimates of animal models.

The genetic correlation between Environment 1 and 2 for each trait was calculated as:

$$
\mathrm{r}_{\mathrm{g}}=\sigma_{\mathrm{s}, 12} /\left(\sigma_{\mathrm{s}, 1} * \sigma_{\mathrm{s}, 2}\right)
$$

where $\sigma_{\mathrm{s}, 12}$ is the sire covariance between environments 1 and 2 , and $\sigma_{\mathrm{s}, \mathrm{i}}$ is the square root of the sire variance in environment $i$.

Differences in estimates of variance components, heritability, and repeatability for the same trait across environments were tested for significance. The standard error of this difference was approximated by taking the square root of the sum of squared standard errors. If the difference was larger than 2 standard errors (95\% confidence interval), the difference was considered significantly different from zero (Lynch and Walsh, 1998).

To test the hypothesis of significant $\mathrm{G} \times \mathrm{E}$, it was investigated whether the genetic correlation deviated significantly from 1 . To obtain approximate confidence intervals, it was assumed that estimates of genetic correlations were normally distributed with variance equal to the standard error squared. The 95\% confidence interval was equal to $\pm 2 \times$ standard error. If the value 1 was within the confidence interval, it was concluded that the genetic correlation was not significantly different from 1 . However, it should be mentioned that the assumption of normality is violated if the estimates of genetic correlation are close to unity (Lynch and Walsh, 1998).

\section{RESULTS}

\section{"Between Farms" Data Set}

Phenotypic means in Table 1 show that test-day yields were very similar between AMS farms and CMS farms; most differences were still significant $(P<0.05)$. Test-day SCS was higher for AMS $(P<0.001)$. In Table 3 , variances of the "between farms" data set are presented. Variances were heterogeneous across milking systems. The residual variance was most heterogeneous, and differences were relatively large $(P<0.001)$. Sire variances and permanent animal variances were relatively less heterogeneous, but still substantially heterogeneous, although sire variances were not significantly different $(P>0.05)$. Variances were more heterogeneous for test-day yield traits than for test-day SCS. All variances were higher for AMS farms than for CMS farms, except sire variance and permanent animal variance of SCS.

Because of a disproportional relative increase in residual variance (Table 3$)$, heritabilities $(P>0.05)$ and repeatabilities $(P<0.001)$ of all traits were lower for AMS farms (Table 4). The difference in heritability and repeatability between AMS farms and CMS farms was largest for test-day fat yield. The repeatability of testday SCS on AMS farms was also substantially lower than the repeatability of test-day SCS on CMS farms. Genetic correlations for test-day yields traits were close to unity. For test-day SCS, the genetic correlation was lower, but the standard error was large. The correlations of test-day fat yield, protein yield, and SCS were not significantly different from unity $(P>0.05)$, although the genetic correlation of test-day milk yield was barely significantly different from unity $(P=0.042)$.

\section{"Within Farms" Data Set}

Phenotypically a small increase in test-day yields can be observed after introduction of AMS, especially between Period 3 and Period 1 (Table 2$)(P<0.001)$. Testday SCS was higher after introduction of AMS $(P<$ 0.001 ), which agrees with literature (Van der Vorst and Hogeveen, 2000; Rasmussen et al., 2001; Kruip et al., 2002).

In Table 5, variances of the "within farms" data set are shown. The phenotypic variance of all test-day yield traits was highest in Period 2. For all traits, the residual variance increased significantly after introduction of AMS $(P<0.001)$. The sire variance of test-day milk yield increased considerably after introduction of AMS, and the relative increase was larger than the relative increase of sire variance of test-day fat and protein yield, although differences in sire variance were not significant $(P>0.05)$. Variances in Periods 2 and 3 were rather similar for test-day yield traits. For test-day SCS, the sire variance and permanent animal variance decreased in Period 2 in favor of the residual variance. The permanent animal variance could recover in Period 
Table 3. Variance components for milk yield (kg), fat yield (g), protein yield (g), and SCS for farms with automatic milking systems (AMS) and farms with conventional milking system (CMS) in the "between farms" data set (SE are presented within parentheses).

\begin{tabular}{llrrr}
\hline Trait & Variance & \multicolumn{1}{c}{ AMS } & CMS & Factor $^{1}$ \\
\hline Milk yield & Sire & $1.58(0.21)$ & $1.10(0.14)$ & 1.44 \\
& Permanent animal & $16.30(0.24)$ & $10.73(0.16)$ & 1.52 \\
& Residual & $8.62(0.05)$ & $5.05(0.03)$ & 1.70 \\
Fat yield & $26.50(0.32)$ & $16.88(0.22)$ & 1.57 \\
& Phenotypic & $1865(265)$ & $1622(223)$ & 1.15 \\
& Sire & $22,447(362)$ & $17,675(281)$ & 1.27 \\
& Permanent animal & $22,581(140)$ & $13,382(82)$ & 1.69 \\
Protein yield & Residual & $46,893(470)$ & $32,678(369)$ & 1.43 \\
& Phenotypic & $1232(178)$ & $811(117)$ & 1.52 \\
& Sire & $14,762(224)$ & $9915(154)$ & 1.49 \\
\multirow{3}{*}{ SCS ${ }^{2}$} & Permanent animal & $10,569(66)$ & $6470(39)$ & 1.63 \\
& Residual & $26,562(293)$ & $17,196(197)$ & 1.54 \\
& Phenotypic & $0.030(0.007)$ & $0.035(0.008)$ & 0.86 \\
& Sire & $1.119(0.019)$ & $1.154(0.019)$ & 0.97 \\
& Permanent animal & $1.279(0.008)$ & $1.063(0.007)$ & 1.20 \\
& Residual & $2.428(0.022)$ & $2.252(0.022)$ & 1.08 \\
\hline
\end{tabular}

\footnotetext{
${ }^{1}$ Factor = variance AMS/variance CMS; this parameter gives information about heterogeneity of variance across milking systems.
}

${ }^{2} \mathrm{SCS}=\log _{2}(\mathrm{SCC})$.

3 to a value almost equal to that during Period 1, and the sire variance increased substantially.

Trends in variances affected variance ratios as heritability and repeatability. For test-day milk yield, the heritability increased after introduction of AMS; for test-day fat and protein yields, the heritability decreased (Table 6) $(P>0.05)$. For test-day SCS, the heritability decreased first and increased to a higher level than before introduction of AMS $(P>0.05)$.

For all traits, the repeatability had the lowest value within $1 \mathrm{yr}$ after introduction of AMS (Period 2; Table 6) $(P<0.05)$. This effect could be due to adaptation problems of the cows and the farmer with respect to AMS. For test-day SCS and fat yield, this effect was quite large. Probably these traits were affected most by different milking frequencies, which could be different within lactation.

Genetic correlations in Table 6 are lower for test-day yield traits and higher for test-day SCS in comparison with Table 4. The genetic correlation between Periods 1 and 3 was lower than the genetic correlation between Periods 1 and 2 . The standard error was larger because genetic links were weaker. Genetic correlations of testday milk yield and protein yield were significantly different from unity $(P<0.05)$ between Periods 1 and 2 and between Periods 1 and 3. The genetic correlation between Periods 2 and 3 was for all traits very close to unity, indicating that these periods can be genetically considered as records of the same trait.

\section{DISCUSSION}

The estimates of genetic correlation indicated little $\mathrm{G} \times \mathrm{E}$ between AMS and CMS. Heritabilities tended to be lower in AMS. The most striking difference between AMS and CMS was that the variances in AMS were much higher than the variances in CMS.

Table 4. Heritability and repeatability for farms with automatic milking systems (AMS) and farms with conventional milking systems (CMS) in the "between farms" data set and the genetic correlation between AMS farms and CMS farms for milk yield, fat yield, protein yield, and SCS (SE are presented within parentheses).

\begin{tabular}{|c|c|c|c|c|c|}
\hline \multirow[b]{2}{*}{ Trait } & \multicolumn{2}{|c|}{ Heritability } & \multicolumn{2}{|c|}{ Repeatability } & \multirow[b]{2}{*}{ Genetic correlation } \\
\hline & AMS & CMS & AMS & CMS & \\
\hline Milk yield & $0.24(0.03)$ & $0.26(0.03)$ & $0.68(<0.01)$ & $0.70(<0.01)$ & $0.93 *(0.03)$ \\
\hline Fat yield & $0.16(0.02)$ & $0.20(0.03)$ & $0.52(0.01)$ & $0.59(0.01)$ & $1.00(0.01)$ \\
\hline Protein yield & $0.19(0.03)$ & $0.19(0.03)$ & $0.60(0.01)$ & $0.62(0.01)$ & $0.98(0.02)$ \\
\hline SCS $^{1}$ & $0.05(0.01)$ & $0.06(0.02)$ & $0.47(0.01)$ & $0.53(0.01)$ & $0.79(0.11)$ \\
\hline
\end{tabular}

${ }^{1} \mathrm{SCS}=\log _{2}(\mathrm{SCC})$.

* Significantly different from unity $(P<0.05)$. 
Table 5. Variance components for milk yield (kg), fat yield (g), protein yield (g), and SCS for different periods ${ }^{1}$ in the "within farms" data set (SE are presented within parentheses).

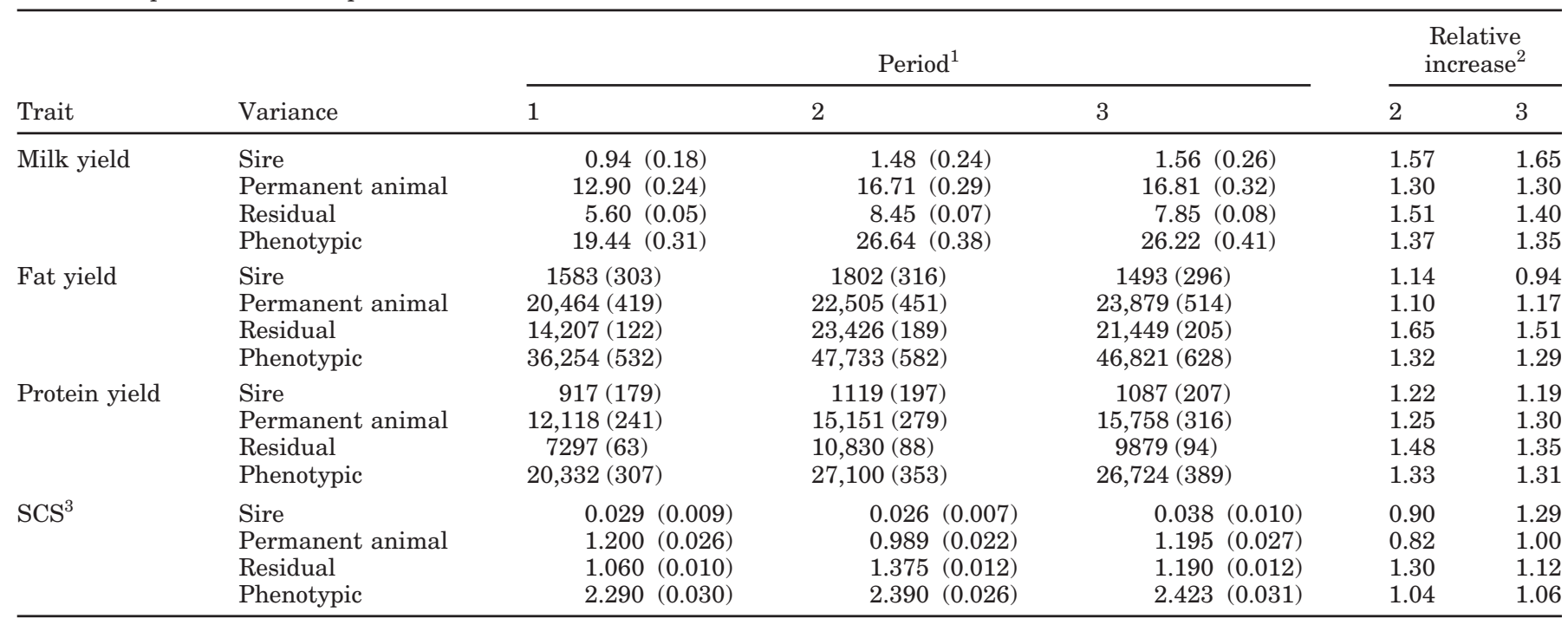

${ }^{1}$ Data were split into 3 periods: 1 ) within $1 \mathrm{yr}$ before introduction of automated milking systems (AMS), 2) within 1 yr after introduction of AMS, and 3) between 1 and 2 yr after introduction of AMS.

${ }^{2}$ Increase in variance of Periods 2 and 3 relative to the variance in Period 1.

${ }^{3} \mathrm{SCS}=\log _{2}(\mathrm{SCC})$.

Genetic correlations between AMS and CMS were lower within farms between different periods than between CMS farms and AMS farms. It seems strange that there is more $\mathrm{G} \times \mathrm{E}$ within the same group of farms than between 2 groups of farms. The most likely explanation is the different composition of the data sets with respect to years of test days. In the case of the "between farms" data set, test-day records during 2000 and 2001 were used for both groups of farms. For the "within farms" data set, test-day records were extracted for each AMS farm from different periods dependent on the introduction date of AMS. Therefore, the defined periods consisted of test-day records from different calendar years.

No literature was found on $\mathrm{G} \times \mathrm{E}$ between $\mathrm{AMS}$ and CMS. However, many studies were performed to consider $\mathrm{G} \times \mathrm{E}$ between different management systems. Weigel et al. (1999) reported genetic correlations between 0.88 and 0.99 between intensive rotational grazing herds and control herds in the US. Weigel et al. (2001) estimated genetic correlations between countries with rotational grazing and intensive management systems between 0.8 and 0.9. Swalve et al. (2001) and König et al. (2002) used data from regions in Western

Table 6. Heritability, repeatability, and genetic correlation of milk yield, fat yield, protein yield, and SCS for different periods in the "within farms" data set (SE are presented within parentheses).

\begin{tabular}{|c|c|c|c|c|c|c|c|c|c|}
\hline \multirow[b]{2}{*}{ Trait } & \multicolumn{3}{|c|}{$\begin{array}{l}\text { Heritability } \\
\text { period }^{1}\end{array}$} & \multicolumn{3}{|c|}{$\begin{array}{l}\text { Repeatability } \\
\text { period }\end{array}$} & \multicolumn{3}{|c|}{$\begin{array}{l}\text { Genetic correlation } \\
\text { between periods }\end{array}$} \\
\hline & 1 & 2 & 3 & 1 & 2 & 3 & 1 and 2 & 1 and 3 & 2 and 3 \\
\hline Milk yield & $\begin{array}{c}0.19 \\
(0.04)\end{array}$ & $\begin{array}{c}0.22 \\
(0.03)\end{array}$ & $\begin{array}{c}0.24 \\
(0.04)\end{array}$ & $\begin{array}{c}0.71 \\
(0.01)\end{array}$ & $\begin{array}{c}0.68 \\
(0.01)\end{array}$ & $\begin{array}{c}0.70 \\
(0.01)\end{array}$ & $\begin{array}{r}0.89 * \\
(0.05)\end{array}$ & $\begin{array}{l}0.87^{*} \\
(0.06)\end{array}$ & $\begin{array}{l}1.00 \\
(0.01)\end{array}$ \\
\hline Fat yield & $\begin{array}{c}0.18 \\
(0.03)\end{array}$ & $\begin{array}{c}0.15 \\
(0.03)\end{array}$ & $\begin{array}{c}0.13 \\
(0.03)\end{array}$ & $\begin{array}{c}0.61 \\
(0.01)\end{array}$ & $\begin{array}{c}0.51 \\
(0.01)\end{array}$ & $\begin{array}{c}0.54 \\
(0.01)\end{array}$ & $\begin{array}{c}0.91 \\
(0.05)\end{array}$ & $\begin{array}{c}0.89 \\
(0.07)\end{array}$ & $\begin{array}{l}>1.00 \\
(0.01)\end{array}$ \\
\hline Protein yield & $\begin{array}{c}0.18 \\
(0.03)\end{array}$ & $\begin{array}{c}0.17 \\
(0.03)\end{array}$ & $\begin{array}{c}0.16 \\
(0.03)\end{array}$ & $\begin{array}{c}0.64 \\
(0.01)\end{array}$ & $\begin{array}{c}0.60 \\
(0.01)\end{array}$ & $\begin{array}{c}0.63 \\
(0.01)\end{array}$ & $\begin{array}{r}0.87 * \\
(0.06)\end{array}$ & $\begin{array}{c}0.85^{*} \\
(0.08)\end{array}$ & $\begin{array}{l}1.00 \\
(0.01)\end{array}$ \\
\hline $\mathrm{SCS}^{2}$ & $\begin{array}{c}0.05 \\
(0.02)\end{array}$ & $\begin{array}{c}0.04 \\
(0.01)\end{array}$ & $\begin{array}{c}0.06 \\
(0.02)\end{array}$ & $\begin{array}{c}0.54 \\
(0.01)\end{array}$ & $\begin{array}{c}0.43 \\
(0.01)\end{array}$ & $\begin{array}{c}0.51 \\
(0.01)\end{array}$ & $\begin{array}{l}>1.00 \\
(0.04)\end{array}$ & $\begin{array}{c}0.95 \\
(0.10)\end{array}$ & $\begin{array}{l}1.00 \\
(0.05)\end{array}$ \\
\hline
\end{tabular}

${ }^{1}$ Data were split into 3 periods: 1 ) within $1 \mathrm{yr}$ before introduction of automated milking systems (AMS), 2) within $1 \mathrm{yr}$ after introduction of AMS, and 3) between 1 and $2 \mathrm{yr}$ after introduction of AMS.

${ }^{2} \mathrm{SCS}=\log _{2}(\mathrm{SCC})$

*Significantly different from unity $(P<0.05)$. 
Table 7. Equilibrium accuracy of selection of bull dams ${ }^{1}$ and $\operatorname{sires}^{2}$ for milk yield under automated milking systems (AMS) or conventional milking systems (CMS) using heritabilities of Table 4 calculated with SelAction (Rutten et al., 2002).

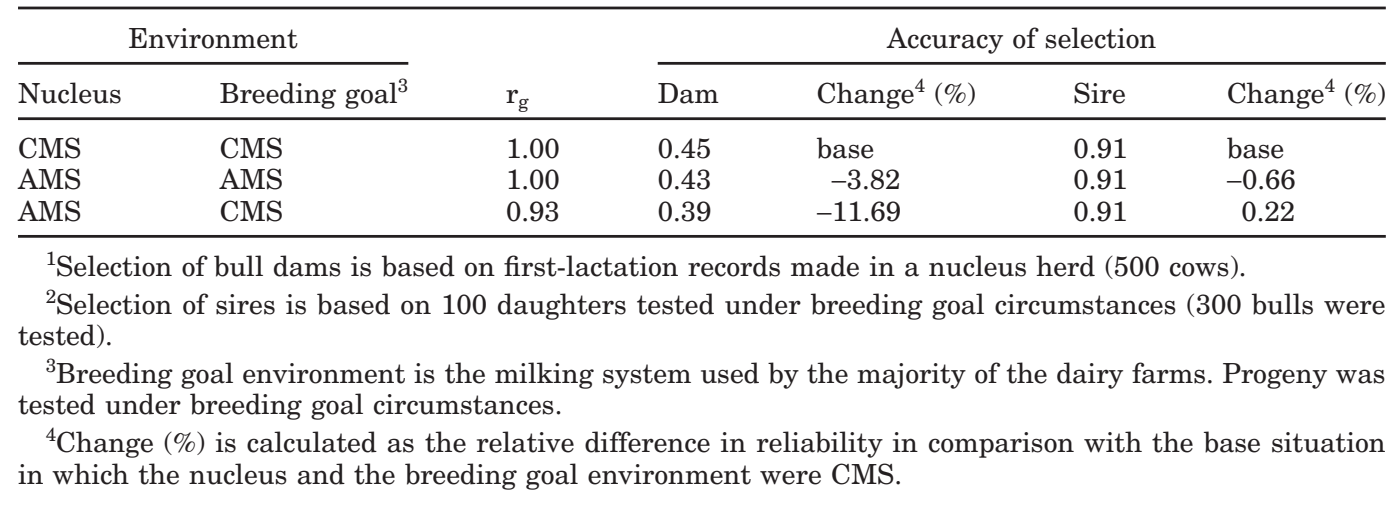

Germany with family farms and data from regions in Eastern Germany with large-scale farms. Genetic correlations were between 0.79 and 0.99 . Although management systems were defined differently than in this study, the range of genetic correlations was very similar compared with the reviewed studies.

Heterogeneity of variance was clearly observed between AMS and CMS in both data sets. A few reasons might explain this phenomenon. First, it could not be explained as a scaling effect (Hill et al., 1983) because the coefficient of variation was heterogeneous as well as a result of remarkably similar phenotypic averages. Second, milking frequency can be different between cows as well as within cows for different test days. These differences could have an effect on production or SCS. Some of these differences are accounted for by the used model, but other differences would increase the residual error. Random regression models (Schaeffer and Dekkers, 1994) or including a fixed effect for milking frequency in the model could probably decrease the residual variance. Data on milking frequency are not yet available for AMS test days.

The results of the "between farms" data set indicate little loss of selection response for AMS farms if selection of sires is based on information from CMS. According to Robertson (1959) a genetic correlation $>0.8$ is of no biological or agricultural importance. Conversely, a genetic correlation $>0.8$ can still result in some re-ranking of bulls, especially within small groups of bulls, such as top bulls. A separate genetic evaluation for AMS is of little value if selection of sires is among progeny-tested sires because progeny would be tested mostly on CMS farms because of the much larger numbers in comparison with AMS farms. However, some farmers may select only old sires with a large number of second-crop daughters. For these farmers, a separate genetic evaluation could have additional value. This group of farmers is probably very small. Another disad- vantage of a separate genetic evaluation is the increase in number of estimated breeding values available to the farmer. Because of these reasons, a multiple-trait evaluation is not recommended. The AMS farms can select sires accurately based on national rankings.

Breeding companies might consider testing their nucleus heifers under AMS conditions. Perhaps in the future, the majority of the farms may be using AMS. Because of changes in heritability and the existence of $\mathrm{G} \times \mathrm{E}$, the accuracy of selection of bull dams and selection of sires might be affected. SelAction (Rutten et al., 2002) was used to calculate the effect of milking system on the equilibrium accuracy of selection of bull dams and sires. Milk yield was the selection criterion. Sires were selected based on the performance of 100 daughters in the breeding goal environment. The breeding goal environment was equal to the milking system of the majority of the farmers. Selection of bull dams was based on first-lactation records in the nucleus herd. Three situations were compared: 1 ) a base situation in which the nucleus and the breeding goal environment are CMS, 2) a situation in which the nucleus and the majority of the farmers are using AMS, and 3) a situation in which the nucleus is using AMS, but the breeding goal environment is still CMS. It was concluded from Table 7 that the accuracy of selection of sires is hardly affected by milking system, which can be explained by the fact that selection of sires is based on progeny testing in the breeding goal environment. Therefore, $\mathrm{G} \times \mathrm{E}$ has no effect. Differences are due to differences in equilibrium heritability. However, if the selection candidates are milked with AMS and the breeding goal environment is AMS as well, the accuracy of selection of bull dams is $3.8 \%$ lower because of a lower heritability. If the breeding goal environment would remain CMS, the decrease is $>11 \%$ because of $\mathrm{G} \times \mathrm{E}$ and a lower heritability. Breeding companies need to be aware of the fact that introduction of AMS in nucleus 
herds could have an effect on the total selection response.

\section{CONCLUSIONS}

Based on the results of this study, it was concluded that little $\mathrm{G} \times \mathrm{E}$ existed between AMS and CMS for test-day yield traits and test-day SCS. The interaction was not very strong and will result in little loss of selection response on AMS farms if selection of sires is almost entirely based on information of progeny in CMS farms. However, the decrease in accuracy of selection of bull dams tested under AMS conditions is considerable if most farmers would continue to milk under CMS conditions.

In most cases, genetic correlations were not significantly different from unity. Genetic correlations in the "within farms" data set were lower for production traits than for SCS; the opposite was observed for the "between farms" data set. Genetic correlations between AMS and CMS were lower within farms between different periods than between CMS farms and AMS farms, which was not expected. Variances were larger in AMS than in CMS. Variances were more heterogeneous for production traits than for SCS. Because of a disproportional increase in residual variance, heritabilities were lower in AMS than in CMS, although differences in heritability were not significant.

\section{ACKNOWLEDGMENTS}

The authors thank NRS (Arnhem, The Netherlands) for providing the data and Abe Huisman and Bart Ducro for assistance with the program ASREML.

\section{REFERENCES}

Ali, A. K. A., and G. E. Shook. 1980. An optimum transformation for somatic cell concentration in milk. J. Dairy Sci. 63:487-490.

Erdman, R. A., and M. Varner. 1995. Fixed yield responses to increased milking frequency. J. Dairy Sci. 78:1199-1203.

Falconer, D. S. 1989. Introduction to Quantitative Genetics. Longman, New York, NY.

Gilmour, A. R., B. R. Cullis, S. J. Welham, and R. Thompson. 1999. ASREML Reference Manual. NSW Agriculture Biometric Bulletin No. 3. NSW Agriculture, Orange, NSW 2800, Australia.
Hill, W. G., M. R. Edwards, M.-K. A. Ahmed, and R. Thompson. 1983. Heritability of milk yield and composition at different levels and variability of production. Anim. Prod. 36:59-68.

Hogeveen, H., W. Ouweltjes, C. J. A. M. De Koning, and K. Stelwagen. 2001. Milking interval, milk production and milk flow-rate in an automatic milking system. Livest. Prod. Sci. 72:157-167.

König, S., H. Simianer, and H. H. Swalve. 2002. Genetic relationships between dairy performance under large-scale farm and family farm conditions estimated from different groups of common sires. Proc. 7th World Congr. Genet. Appl. Livest. Prod., Montpellier, France. 32:375-378.

Kruip, T. A. M., H. Morice, M. Robert, and W. Ouweltjes. 2002. Robotic milking and its effect on fertility and cell counts. J. Dairy Sci. 85:2576-2581.

Lynch, M., and J. B. Walsh. 1998. Genetics and Analysis of Quantitative Traits. Sinauer Associates, Inc. Publishers, Sunderland, MA.

NRS. 2002. Handboek NRS. (Handbook NRS). Chapter E-7. Fokwaardeschatting melkproductiekenmerken met testdag model. Koninklijk Nederlands Rundvee Syndicaat, Arnhem, The Netherlands.

Peeters, R., and P. J. B. Galesloot. 2002. Estimating daily fat yield from a single milking on test day for herds with a robotic milking system. J. Dairy Sci. 85:682-688.

Rasmussen, M. D., J. Y. Blom, L. A. H. Nielsen, and P. Justensen. 2001. Udder health of cows milked automatically. Livest. Prod. Sci. 72:147-156.

Robertson, A. 1959. The sampling variance of the genetic correlation coefficient. Biometrics 15:469-485.

Rutten, M., P. Bijma, J. A. Woolliams, and J. A. M. Van Arendonk. 2002. SelAction: Software to predict selection response and rate of inbreeding in livestock breeding programs. J. Heredity 93:456-458.

Schaeffer, L. R., and J. C. M. Dekkers. 1994. Random regressions in animal models for test-day production in dairy cattle. Proc. 5th World Congr. Genet. Appl. Livest. Prod., Guelph, Canada, 18:443-446.

Schaeffer, L. R., J. Jamrozik, G. J. Kistemaker, and B. J. Van Doormaal. 2000. Experience with a test-day model. J. Dairy Sci. 83:1135-1144.

Swalve, H. H. 2000. Theoretical basis and computational methods for different test-day genetic evaluation methods. J. Dairy Sci. 83:1115-1124.

Swalve, H. H., S. König, G. Dietl, and I. Räder. 2001. Genetic relationships between dairy performance under large-scale farm and family farm conditions. Page 71 in Proc. 52nd Annu. Mtg. EAAP, Budapest, Hungary. (Abstr.)

Van der Vorst, Y., and H. Hogeveen. 2000. Automatic milking systems and milk quality in the Netherlands. Pages 73-82 in Robotic milking-Proc. Int. Symp., Lelystad, The Netherlands. H. Hogeveen and A. Meijering, ed. Wageningen Pers, Wageningen, The Netherlands.

Weigel, K. A., T. Kriegl, and A. L. Pohlman. 1999. Genetic analysis of dairy cattle production traits in a management intensive rotational grazing environment. J. Dairy Sci. 82:191-195.

Weigel, K. A., R. Rekaya, N. R. Zwald, and W. F. Fikse. 2001. International genetic evaluation of dairy sires using a multiple-trait model with individual animal performance records. J. Dairy Sci. 84:2789-2795.

Wilmink, J. B. M. 1987. Adjustment of test-day milk, fat and protein yield for age, season and stage of lactation. Livest. Prod. Sci. 16:335-348. 